\title{
Do firearms link organised crime and terrorism in the Netherlands? A Social Network Analysis exploration
}

\author{
Niels van Wanrooij and Saraï Sapulete ${ }^{1}$
}

\section{Introduction and research question}

\section{a. Introduction}

Attacks by (jihadi) terrorists have become more frequent over the past decade. As the neighbouring countries experienced more frequent and more deadly terrorist attacks (see Figure 1), the Dutch authorities grew increasingly concerned about the possibility of similar attacks happening in the Netherlands. In particular, the threat of Dutch (jihadi) terrorists acquiring heavy firearms to conduct Bataclan-like attacks loomed in the back of policymakers' minds. Preventing such heavy firearms from falling into the wrong hands became a top policy priority. In 2016, this led the Dutch Ministry of Justice and Security to commission a study on how firearms are acquired by terrorists, specifically

1 The authors are research consultants at Ecorys Netherlands, an international research and consultancy organisation. This chapter is based on a study for the Scientific Research and Documentation Centre (WODC) of the Dutch Ministry of Justice and Security, which was completed by a project team consisting of Dr. Brigitte Slot, Dr. Saraï Sapulete, Niels van Wanrooij MSc (Ecorys) and Ms. Monique Bruinsma (Bureau Bruinsma) in 2016-2017. We are very grateful for the assistance by the WODC and by the generous collaboration offered by the National Police, especially by one of their analysts- who aided our data collection immensely - as well as the National Team Firearms Expertise and the National Team Counter-Terrorism and Radicalism. 
looking at interactions between firearms dealers, organised crime, and terrorists (suspects).

Figure 1.

Selected terrorist attacks in Europe, 2004 - 2017

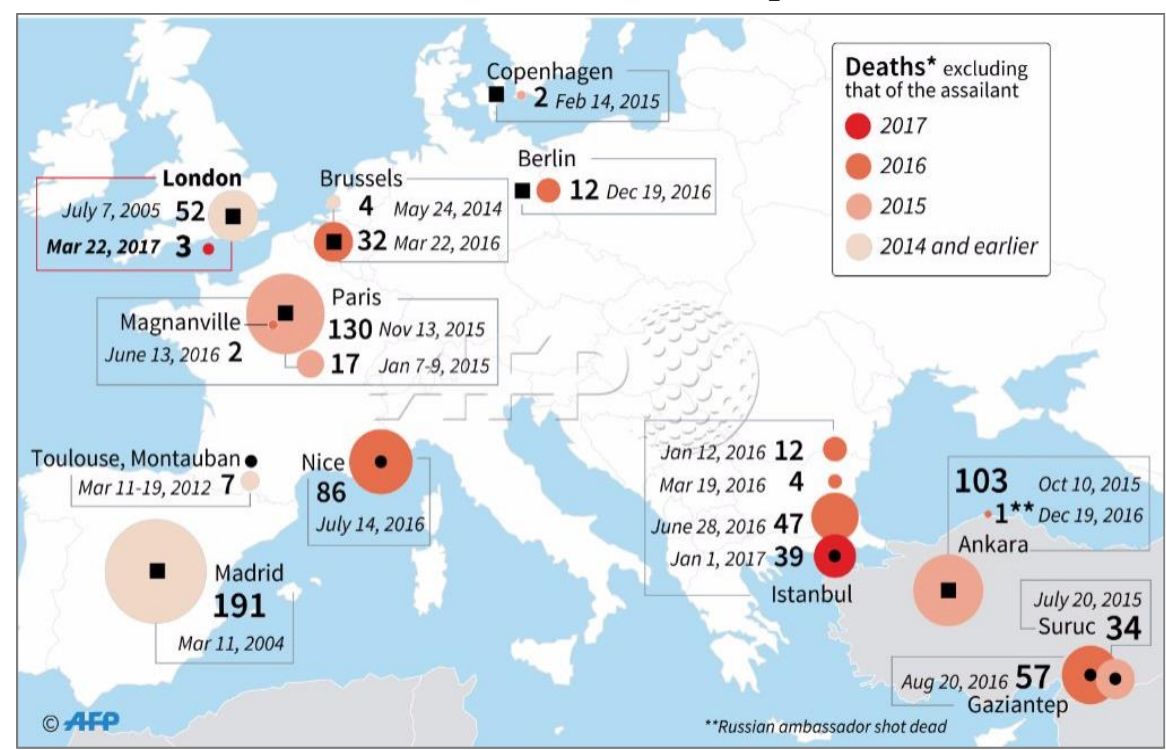

Source: AFP

An extensive literature exists on the presumed connection between organised crime and terrorism, in academia (for example, Laqueur, 2000; Makarenko, 2004; Basra, Neumann and Brunner, 2016) and, in line with the development of the phenomenon in Europe, in European policy papers (for example Makarenko and Mesquitaa, 2014; West Sands Advisory LLP, 2012; Renard, 2016; Adviesraad Internationale Vraagstukken, 2013). In addition, much has been written specifically about how the firearms trade operates in Europe (Centre for Strategy and Evaluation Services, 2014; Flemish Peace Institute, 2018) and on the firearms used in mass shootings (Duquet, 2016).

At the same time, while media report about the routes travelled by jihadis and their firearms proliferated (see Figure 2; Der Spiegel, 24 March 2016; NRC, 15 July 2016;) very little empirical research is conducted on the relationship between terrorism and organised crime (Hübschle, 2011). Although presumably intelligence services and law enforcement agencies have access 
to the relevant data - and one expects they exploit this data to counteract potential threats - such information is not shared with the public. While this is understandable from the point of view of law enforcement, it does not help address questions about the (development of the) nature of the phenomenon, hampering a better understanding and a public debate on the issues.

Figure 2.

Delivery route of firearms used in terrorist attacks in Europe

Weapons

without Borders

The uncontrolled routes taken

by firearms, also used in terror

attacks, to Western Europe

$\rightarrow$ lethal firearms

$\rightarrow$ firearms that have been deactivated but can be easily reactivated

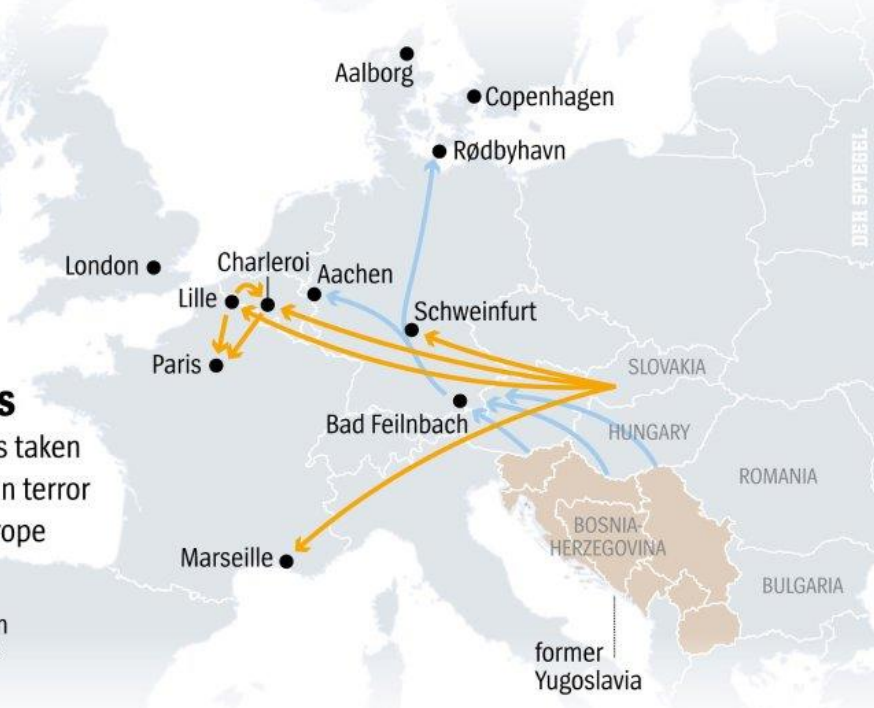

Source: Der Spiegel (24 March 2016)

\section{b. Research question}

Two main assertions follow from the literature on the organised crime-terror nexus. On the one hand, terrorist groups are posited to increasingly act like organised crime groups in order to obtain their money. On the other hand, profit-maximising criminal groups will not ask too many questions when they are able to sell their products to whomever, jihadis included. 
Research regarding the profiles of Dutch jihadi terrorists has shown that in many cases, they have a criminal history (Poot and Sonnenschein, 2009; Bie, 2016). Research by Veldhuis (2016) implicates prisons as pivotal locations where criminals and terrorists meet, and in some cases petty criminals can be recruited as terrorists. It seems the attacks in Paris (2015) and Denmark (2015) were committed by petty criminals thus recruited (NCTV, 2015). The terrorists were able to rely on their old criminal networks to obtain their firearms, and the suppliers of the firearms seem not in all cases to be aware that their old buddy has become a terrorist.

The situation described above holds for the case of the Netherlands as well: although there is a reliable literature on the operation of the firearms trade (Boerman and Bruinsma, 2012; Bruinsma and Moors, 2005; Dienst Nationale Recherche, 2006; NRC, 13 July 2016a; 13 July 2016b), and an emerging literature on Dutch terrorist networks (Bie, 2016; Poot and Sonnenschein, 2009), empirical research on the link between the two is lacking. The scientific department of the Dutch Ministry of Justice and Security recognised this gap and commissioned a study on the situation in the Netherlands.

After conducting a literature review on how Dutch (jihadi) terrorist groups acquire their firearms, the study sought to answer the following research question with regard to organised crime and terrorists:

Are organised crime and jihadi terrorist networks in the Netherlands interwoven? If so, what does this interwovenness look like?

The concept 'interwoven networks' is defined as follows: the lack of a clear boundary between two networks, characterised by a (partial, but structural) overlap of networks. As applied and operationalised in our Social Network Analysis (SNA) methodology, overlapping networks would be characterised by members of a network being part of both an organised crime network and a jihadi terrorist network.

This question has been explored by way of a SNA (Social Network Analysis on a specific case, namely that of the Slovakian firearms dealer AFG (see below). The identification of the starting group was crucial to the potential of the study itself. An extensive consultation was organised to identify the most relevant, and potentially fruitful 'case', and inputs were gathered from experts 
at the National Police, the Public Prosecutor's Office, the counter-terrorism coordinator (NCTV), and the intelligence service (AIVD).

The SNA was thus applied to a major case involving organised crime, firearms dealers and - as became apparent - terrorist suspects. The study can best be understood as an explorative case study (Gerring, 2007) where a tentative link is explored and opportunities for further research are developed.

\section{Research design}

\section{a. Social network analysis}

The main body of the study consisted of a Social Network Analysis. Such an analysis provides a method to study social structures. The focus is not on individual actors (or nodes), but on the relationships between them. Actors can be individuals, but also organisations, countries, etc. The relationship can be defined by several types of links, e.g. kinship, friendship, financial transactions, etc. Social network analysis thus gives us a "formal, conceptual means for thinking about the social world" (Wasserman and Faust, 1994). The social network analysis method gives an in-depth insight into the dynamics and links between actors. Moreover, it allows for identifying main actors and their function (e.g. connectors, influencers) within the network.

Social network analysis provides added-value by showing not only how actors are interlinked but also who are the essential actors within a particular network. Moreover, a social network analysis allows for an easy comparability with other networks by analysing the network characteristics (fragmented or fully connected structures) and the ease of interaction (ability to form connections) between actors.

\section{b. The case: the AFG firearms dealer}

Since 2014, European law enforcement investigators have been observing the Slovakian (web)shop AFG, located in the small town of Partizánske. This shop sells deactivated firearms throughout Europe on their premises and via 
their website (see Figure 3). The German Bundeskriminalamt (Federal Police) estimated in 2016 that some 14.000 of these firearms were in circulation in the EU. These firearms were deactivated in a way that made reactivation into 'live' firearms relatively easy. Because of a loophole in European legislation this method of deactivation was legal at the time, even if reactivating them was not.

This presented an opportunity and an easy supply of firepower to satisfy the demands of actors with malicious intent, both criminals and terrorists. And indeed, reactivated firearms from this 'AFG line' have made their way to French terrorists, UK gangsters, and German neo-Nazis (Der Spiegel, 24 March 2016).

Figure 3.

\section{Deactivated submachine gun (CZ vz 58) on AFG web shop}

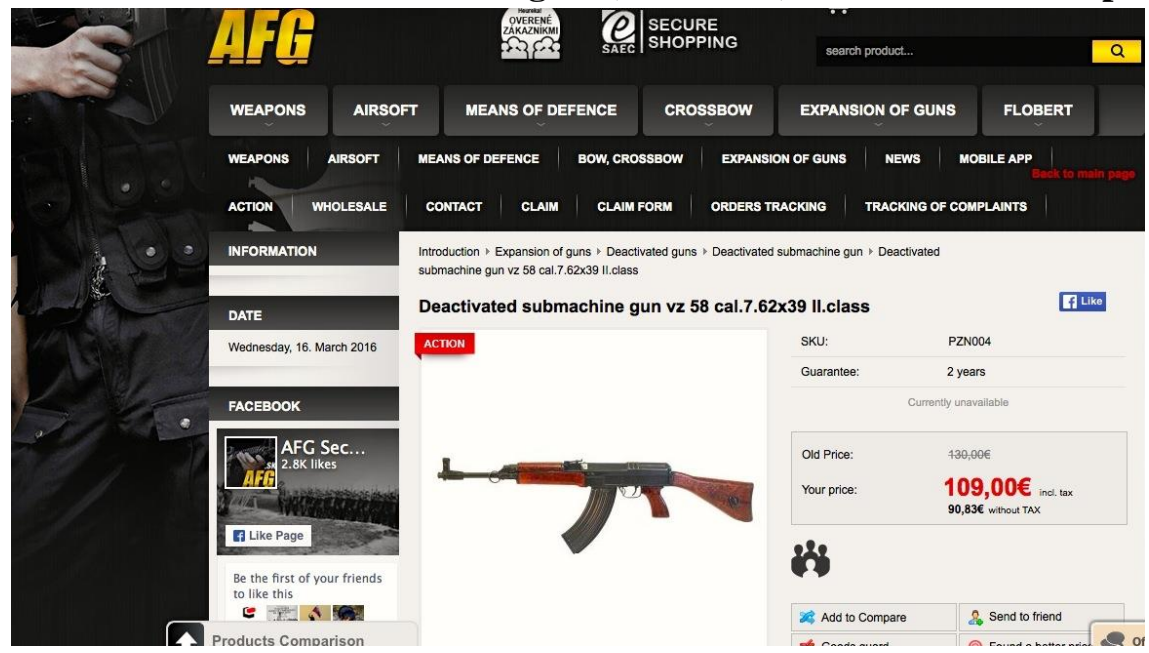

Source: AFG website

The most recent Dutch National Threat Assessment (Nationaal Dreigingsbeeld, 2017) indicates that such reactivated firearms make up a large proportion of the supply of firearms in the Netherlands, with almost 200 'recycled' automatic firearms found since 2012: rifles from manufacturer CZ akin to the famous AK 47, Skorpion machine-pistols as well as various pistols. Crucially, police investigations show that the majority of these firearms can 294 
be traced back to the AFG webshop, with (illegal) reactivation taking place in Germany or the Netherlands.

While it is unclear exactly how many steps there are between reactivation of the firearms and their appearance on the market, it is clear that the final step before reaching the 'customer' was through (illegal) firearms dealers. Within the context of this study, it is this latter group of firearms dealers that represents the salient network(s) of organised crime.

Because of this case's importance for law enforcement, the National Police had started to compile an AFG-database listing details about the apprehensions and investigations where AFG firearms were found, including which persons were present when a firearm was discovered, how they were connected to the firearm(s) (such as 'in possession at time of apprehension', 'present but not in possession') and whether there had been active police investigations into these persons. In total, more than 2.000 persons were listed in this way. This provided a rich data source that was leveraged as the starting point for the SNA.

As it was known that firearms dealers were involved in this case, our research question could focus on whether, starting from this group, connections to terrorist cells could be discovered.

\section{c. Data collection}

Following the identification of the relevant case, the framework for the Social Network Analysis was developed. This was done by developing a data collection protocol (which criteria are relevant to our research questions), and a database template.

Our research adopted an open-ended approach: neither the size of the group nor the individuals within it were known beforehand. The only 'known' was the point of departure: the initial group of subjects whose social network 
would be mapped. Their connections, and their connections' connections, became only (fully) known during the course of the data collection. ${ }^{2}$ Theoretically, the pool of people in the databases could have been known if all of them were researched beforehand, but the salient relations between subsections of them could not have been. ${ }^{3}$

The study was able to draw on 'raw' police data present in the various databases of the Dutch National Police: information on the criminal record and history of apprehensions, arrests and convictions of all Dutch citizens, as well as information about family relations. Working arrangements were made to work on-site at the National Police premises, so that queries of these databases were either performed or supervised by an authorised police analyst at all times. The extracted information has been coded, anonymised and processed into a large database, indicating the personal characteristics and relations between (code-named) subjects.

To be able to work with the case, the group of over 2.000 subjects had to be reduced. First, this was necessary as it included many subjects that were simply not relevant for our purposes: innocent bystanders; (deceased) victims; those with only a very tenuous link to firearms. Second, as SNA is a labourintensive methodology that increases the number of subjects included exponentially with each step, the starting group needed to be as small and focused as possible to avoid the noise overpowering the signal. We limited our file analysis to persons with a criminal record (persons implicated as suspects and those convicted of crimes).

To focus our efforts and eliminate non-relevant persons, a number of steps were followed to filter the 700 remaining subjects into three relevant roles. First, a distinction was made between those subjects that had been found in direct possession of a firearm, and those that had not been. The former were assigned the role of firearms possessor.

2 This is in contrast to when an SNA is applied to, for example, a typical company, where all the relevant persons (the employees) are known to the researchers beforehand.

3 The only way this would have been possible is if it had been possible to engage with the detectives who handled the investigations. (This would have had the drawback of potentially steering the focus of the SNA towards particularly vivid cases for these investigators.) 
Separately, the whole dataset was cross-checked in two ways:

1. With police experts on the Dutch firearms trade, to identify (known) firearms dealers - the second role in our SNA;

2. With police experts monitoring extremists and (known) terrorists, to identify (suspected) terrorists - the third role in our SNA.

Those subjects that were not assigned any of the three roles were subsequently expunged from our dataset. Following these steps, we obtained a list of 40 persons divided into three relevant roles: 5 firearms dealers; 15 terrorist suspects; 20 firearms possessors. Every person was assigned a single role. Logically, those identified as firearms dealers and terrorist suspects could also have possessed firearms, while those in the firearms possessors subgroup could not have been identified as firearms dealers or suspected terrorists as this would have meant changing their classification.

This group of 40 formed the starting point of the SNA. We then proceeded with 'snowball sampling' from our focal actors: each individual's police file had a section elaborating the individuals associated with it through past (suspected) crimes. This list of co-suspects and -convicts was added to the SNA as a first layer of contacts. Each of these newly added individuals was subsequently subjected to the same exercise, again analysing their police file for persons associated through past (suspected) crimes.

While building our database, we collected both relational and personal attributes. The relational attribute answered whether subject $a$ had a relation to subject $b$, based on association in their criminal record (they had been apprehended and/or convicted together in one or more cases). We also noted recorded whether these persons were identified as firearms dealers, terrorist suspects (labelled 'CTER actors' to distinguish them from the start group) or firearms possessors. An overview of the data groups used in the study is given in Table 1. 
Table 1.

Data groups used in the study

\begin{tabular}{|l|l|}
\hline Data group & \multicolumn{1}{|c|}{ Definition } \\
\hline Starting group & $\begin{array}{l}40 \text { persons identified from the AFG case, comprised of } \\
\text { the 3 subgroups 'firearms dealers', 'terrorist suspects', } \\
\text { and 'firearms possessors'. }\end{array}$ \\
\hline $\begin{array}{l}\text { Firearms dealers } \\
\text { [start group] }\end{array}$ & $\begin{array}{l}5 \text { persons from the AFG case identified by police ex- } \\
\text { perts as known firearms dealers in the Netherlands }\end{array}$ \\
\hline $\begin{array}{l}\text { Terrorist suspects } \\
\text { [start group] }\end{array}$ & $\begin{array}{l}15 \text { persons from the AFG case identified by police ex- } \\
\text { perts as terrorist suspects in the Netherlands }\end{array}$ \\
\hline $\begin{array}{l}\text { Firearms possessors } \\
\text { [starting group] }\end{array}$ & $\begin{array}{l}20 \text { persons from the AFG case with a conviction for a } \\
\text { firearms-related offence }\end{array}$ \\
\hline CTER actors & $\begin{array}{l}\text { All persons in the SNA database, identified as terrorist } \\
\text { suspects in the Netherlands by police experts }\end{array}$ \\
\hline Firearms possessors & $\begin{array}{l}\text { All persons in the SNA database, identified as having a } \\
\text { conviction for a firearms-related offence }\end{array}$ \\
\hline
\end{tabular}

\section{d. Measures}

Key in social network analysis is the concept of centrality. A strong, central network position of an actor is not only determined by the number of contacts the actor has, but also by the position the actor holds in the network, and the connectedness of his or her contacts. The following structural network characteristics define the centrality of actors (see e.g., Freeman et al. 1991, Borgatti 2005):

- Degree centrality. Degree centrality measures the number of relations an actor has with other actors. It is higher the more connections an actor holds with other actors. In a directed - or asymmetric - network, we distinguish in-degree and out-degree, being the number of incoming ties, and the number of outgoing ties.

- Betweenness centrality. Betweenness centrality measures the importance of one actor in acting as a bridge between actors who would otherwise not be connected (Burt, 1992). These connecting actors do not necessarily need to have a high degree centrality but need just to act as a bridge between 
two distant communities. By taking the position between two non-connected groups, a 'structural hole' is filled (Burt, 1992). Taking such a bridge position is also known by the term 'brokerage' . Betweenness centrality is measured by the number of times an actor fulfils a bridge position on the shortest path (defined by the number of dyadic ties) between two other actors within the network.

- Closeness centrality. Closeness centrality measures the distance of one actor to all other actors in the network. The more direct relations exist between actors, the higher closeness centrality is. It can be regarded as a measure of how long it will take to spread information from one actor to all other actors. Closeness centrality is calculated via the sum of the length of the shortest paths between an actor and all other actors in the network.

- Eigenvector centrality. Eigenvector centrality takes into account the relative importance of the relations of actors, instead of merely the number of relations. In networks that are larger and more complex, measuring only closeness centrality does not always suffice. Eigenvector centrality provides a relative score, in which actors who have relations with more central actors, score higher than actors with the same number of relations, but with less central actors. Thus, actors with high eigenvector centrality have more relations to others who are themselves well-connected.

\section{Findings}

\section{a. Network characteristics}

The 40 key actors who were central to our analysis have led to a network of 724 actors, who have 4.340 connections with each other, defined by (suspected) co-offending ties (see Table 2). This is a low density or sparse network, indicated by the network density of $0,8 \%$, meaning $0,8 \%$ of all possible relations between the actors has been established. Of course, the nature of the 
network is a logical consequence of the methodological choice to base relations solely on associations through a criminal record. It remains an open question what this says about the density of the underlying social networks.

Furthermore, we see that the network exists of 22 components, which are isolated from each other. Based on our data collection and analysis, we see no overarching network emerging. This is (also) a consequence of our method of snowball sampling starting with 40 focal actors (start group), which were not connected to each other up-front.

Table 2.

Network characteristics

\begin{tabular}{|l|r|}
\hline Aspect & Number \\
\hline Actors & 724 \\
\hline CTER actors identified & 108 \\
\hline CTER actors currently under investigation & 37 \\
\hline Connections & 4.340 \\
\hline Density & 0,008 \\
\hline Components & 22 \\
\hline
\end{tabular}

We have identified nine of the 22 components as crucial for answering our research question, based on the following indicators:

1. The component "DEALERS" contains all five identified firearms dealers;

2. Seven of the components contain terrorist suspects (TERROR $1-7$ );

3. One of the components (TERROR 8) identifies terrorist suspects in the network of a person in the start group.

The other network components are either too small or contain no relevant subjects from our starting group. We first describe the network characteristics of the start group, followed by a description of the components in detail.

As we do not have information on the complete network of all actors identified, the network measures are skewed for those actors in the start group: because we have more information for the start group, their centrality is higher by definition. Therefore, we report the centrality measures regarding our 40 persons from the start group. The centrality measures are based on the centrality within the component the actor is located in. We have presented the 
measures for the firearms dealers, terrorist suspects as well as the start group as a whole.

Table 3.

Degree centrality start group

\begin{tabular}{|l|c|c|c|}
\hline Group & Mean & Min - max & N \\
\hline \multicolumn{3}{|c|}{ Degree centrality } \\
\hline Start group & 18,8 & $3-73$ & 40 \\
\hline Firearms dealers & 11,6 & $3-19$ & 5 \\
\hline $\begin{array}{l}\text { Terrorist suspects } \\
\text { (start group) }\end{array}$ & 24,5 & $3-73$ & 15 \\
\hline Closeness centrality & 0,01 & $(0,00-0,11)$ & 40 \\
\hline Start group & 0,00 & $(0,00-0,00)$ & 5 \\
\hline Firearms dealers & 0,02 & $(0,00-0,11)$ & 15 \\
\hline $\begin{array}{l}\text { Terrorist suspects } \\
\text { (start group) }\end{array}$ & \multicolumn{3}{|l|}{} \\
\hline Betweenness centrality & $(0-5,09)$ & 40 \\
\hline Start group & 0,57 & $(0-0,40)$ & 5 \\
\hline Firearms dealers & 0,19 & $(0-5,09)$ & 15 \\
\hline $\begin{array}{l}\text { Terrorist suspects } \\
\text { (start group) }\end{array}$ & 0,80 & $(0-0,69)$ & 40 \\
\hline Eigenvector centrality & $(0-0,30)$ & 5 \\
\hline Start group & 0,27 & $(0-0,56)$ & 15 \\
\hline Firearms dealers & 0,07 & & \\
\hline $\begin{array}{l}\text { Terrorist suspects } \\
\text { (start group) }\end{array}$ & 0,23 &
\end{tabular}

For degree centrality, we see an average score of 18,8 indicating that actors in the start group are related to an average of about 19 other nodes in their respective components. The maximum of actors someone is related to is 73 in the case of a terrorist suspect, which skews the average of the terrorist suspects group (average of 24,5). The average degree centrality score for the firearms dealers is lower $(11,6 ; \mathrm{N}=5)$. Terrorist suspects $(\mathrm{N}=15)$ have more relations than firearms dealers. The other centrality measures also indicate that terrorist suspects are more central than firearms dealers. 


\section{b. Network of firearms dealers}

After looking at the start group, we zoom in on the relevant components. All firearms dealers can be found in one component with 55 actors (component DEALERS; see Figure 4). In this sense, the SNA 'shows' that they are part of the same space in the underworld. At the same time the firearms dealers have a rather peripheral position in the overall network of 724 actors. Relatively speaking they do not have many connections and do not occupy a central position.

The firearms dealers are not all connected to each other directly, and mostly fulfil bridge positions to each other's ego-centric networks (see Figure 4). Weapon dealers 1 and 2 score high on betweenness centrality in component DEALERS: they connect other networks of actors within the component. Weapon dealer 4 scores highest on eigenvector centrality, indicating he has most relations to others who are themselves well-connected.

\section{Figure 4.}

\section{Component DEALERS, five firearms dealers}

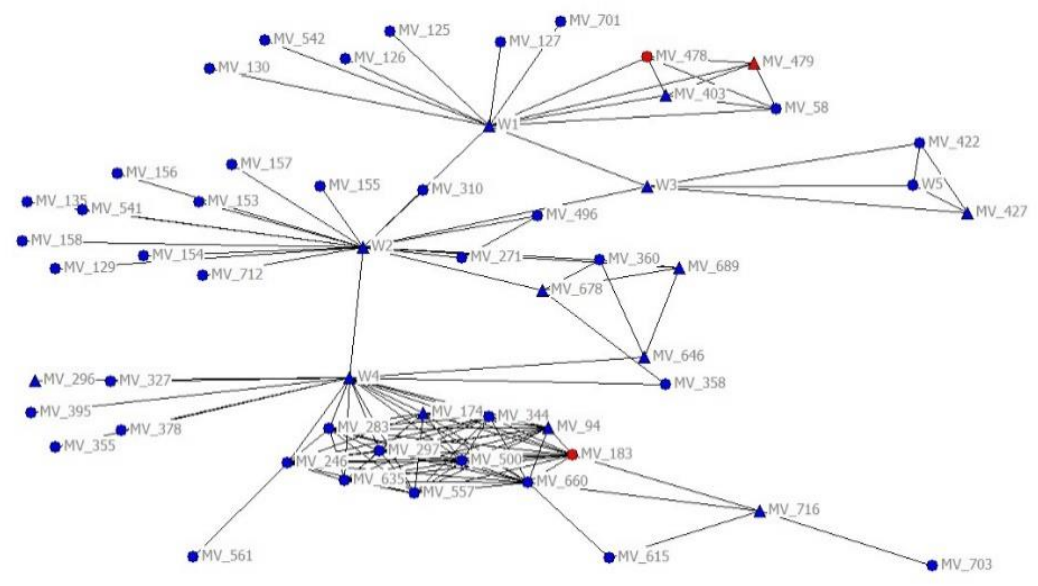

Legend:

- W1-W5: firearms dealers

- Red: present on the CTER suspect list

- Triangle: convicted for firearms possession ('Wwm-feit' under Dutch law), proxy for possessor of firearms 
Furthermore, there are three actors in this sub-network, who are in the CTER database. Two of these have a direct connection to one of the firearms dealers. This indicates that firearms dealers are in direct contact with subjects that are flagged as persons of interest regarding potential terrorist motives. These actors are highly likely to be able to obtain firearms from their connections.

\section{c. Networks of terrorist suspects}

We identified seven components around terrorist suspects in our start group (see Figure 5). Within these components, there are almost invariably subjects that have been found to be in possession of firearms. In other words, in most cases firearms are in circulation within the networks of terrorist suspects. One can surmise these would be relatively easy to acquire by these subjects.

Figure 5 shows the seven components. This visualisation reveals that the size of these sub-networks varies substantially, ranging from 4 to 204 actors per component. As a consequence of our data collection method, the terrorist suspects have most connections. Several clusters within the components in which they are prominently represented, are connected by bridging actors. In other networks, the terrorist suspects fulfil bridge positions themselves.

In component TERROR 1 there are 38 actors. One of the terrorist suspects (red triangle) is most central, and also convicted for firearms possession. Component TERROR 2 is the largest component with 204 actors. Again, one of the terrorist suspects is most central in this component. Furthermore, a number of actors who are not included in the start group have been identified as central. Component TERROR 3 is the smallest component, with 4 actors, 2 of which are terrorist suspects. Both of them are connected to all others in the component, while no direct link exists between the two non-terrorist suspects.

Component TERROR 4 contains 81 actors, who are connected by two central bridge positions, fulfilled by terrorist suspects, who have been also convicted for firearms possession. Component TERROR 5 consist of 21 actors, built around a terrorist suspect. Four other actors - outside of the start group, but known in the terrorist database - are identified as being highly central in the component. Those four actors are all directly connected to the terrorist suspect in the most central position. 
Component 6 consists of 112 actors. In this network, two terrorist suspects and three non-start group actors are highly central. The terrorist suspects score high on eigenvector centrality, while the non-start group actors mostly have high scores regarding betweenness centrality. Finally, component 7 contains 22 actors, revolving around one central terrorist suspect.

The information from these components reveals that the terrorist suspects are (indirectly) connected to each other within the components, but also to a large network of persons with a criminal background, especially visible in subnetworks 2 and 6. Also, weapons are within arm's reach for many actors within these components. This may indicate that terrorist suspects can obtain a firearm relatively easily.

Figure 5.

Components containing terrorist suspects

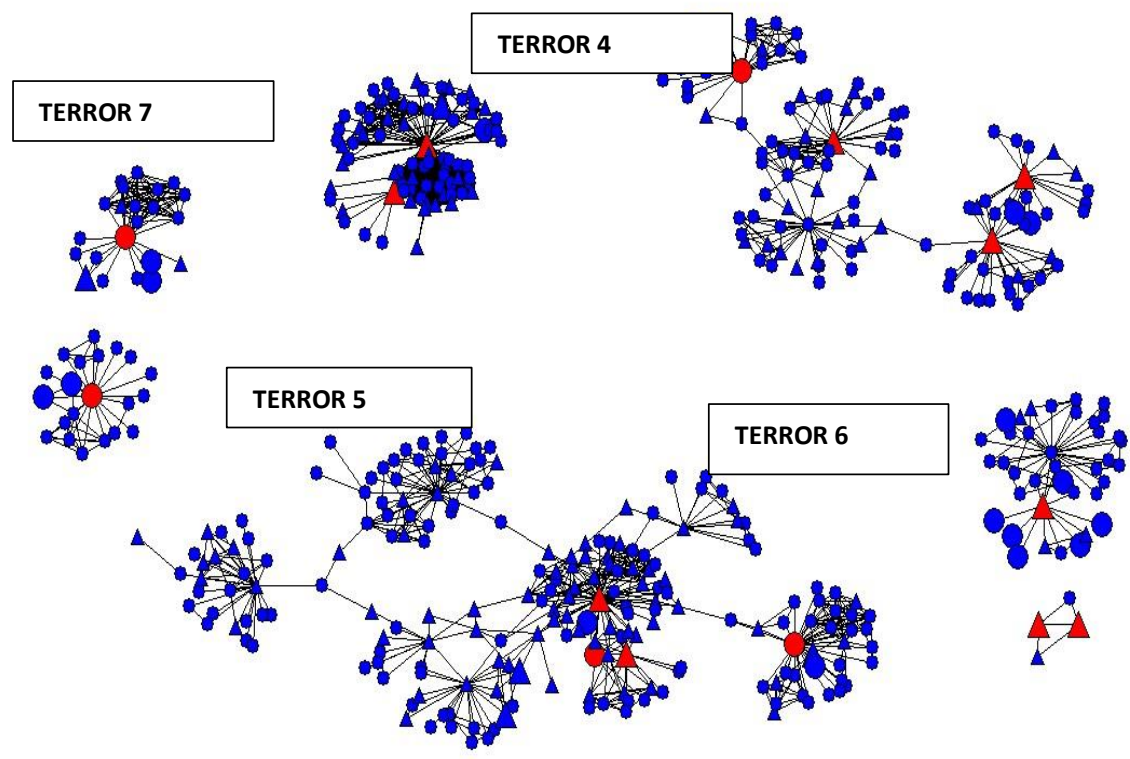

Legend:

- Red: terrorist suspects part of start group

- Size: bigger symbol indicates subject now or in the past under active investigation on counter-terrorism concerns

- Triangle: convicted for firearms possession ('Wwm-feit' under Dutch law), proxy for possessor of firearms 


\section{d. Network with identified terrorist suspects}

Apart from the component including the five arms dealers, and the seven components comprising terrorist suspects, there is a ninth component (TERROR 8; see Figure 6) relevant for our analysis, which revolves around an actor identified in the start group who is neither an arms dealer nor a suspected terrorist. This individual (SG_13) was identified in the start group due to a direct link to an AFG-weapon (for which he had not been convicted during the timespan of our study). In drawing up the connections of this individual (SG_13), four actors were identified who are known in the terrorist database, and of which one was known in a terrorist investigation at the time of our study.

Component TERROR 8 consists of 27 actors, of which SG_13 as well as three other individuals occupy the most central positions. One of the latter three individuals (MV_560) is known in the terrorist database. The connection between SG_13 and MV_560 may indicate a relation between AFG and terrorism given SG_13's direct link to an AFG sourced weapon.

Figure 6.

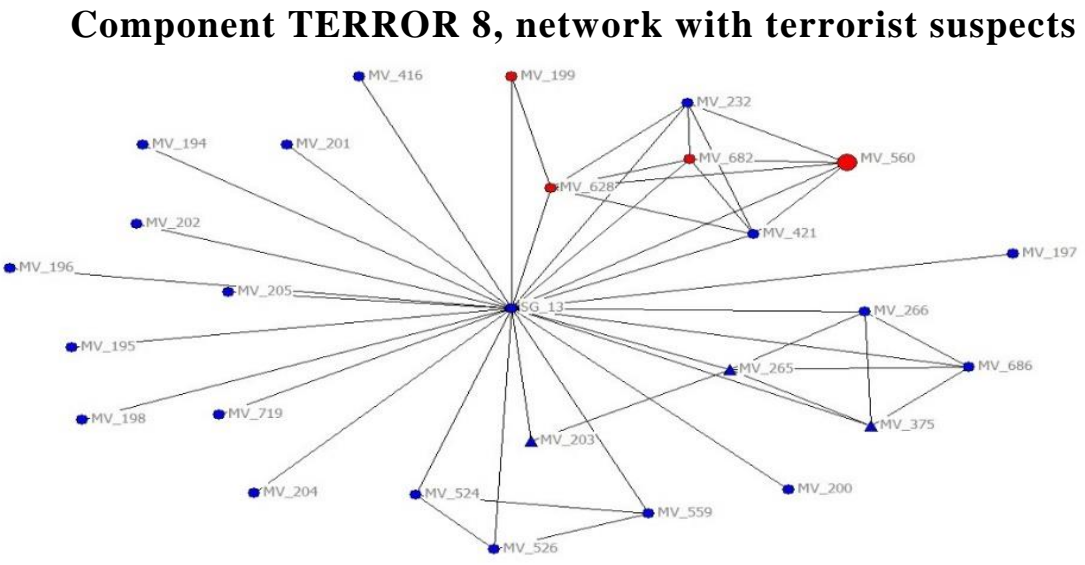

Legend:

- Red: terrorist suspects part of start group

- Size: bigger symbol indicates subject now or in the past under active investigation on counter-terrorism concerns

- Triangle: convicted for firearms possession ('Wwm-feit' under Dutch law), proxy for possessor of firearms. 


\section{Conclusion}

\section{a. On acquisition of firearms}

In this section we reflect on how the findings relate to the research question and draw a number of (tentative) conclusions.

At an early stage of the case study, it became clear that the terrorist suspects had access to firearms from the AFG supply line. Crucially, within the 'firearms dealers network' (component 10) we have identified several terrorist suspects who have either a direct (one step) or indirect (two steps) link to these dealers. Further research (or police investigation) at subject-level into how exactly they acquired those firearms would be fruitful. However, the characteristics of the network(s) arising from our SNA indicates it is highly likely these were directly or indirectly acquired via Dutch firearms dealers, seems to lend support to what we would expect based on the alleged crime-terror link discussed in the (academic) literature.

\section{b. On the interwovenness of organised crime and terrorism}

At the same time, some of our findings are noteworthy. Most importantly, our case study does not show evidence that there is an interwovenness between organised crime and terrorism. This conclusion can be broken down into a number of distinct elements.

The results of our case study seem to imply that the firearms trade in the Netherlands can rightly be considered as 'organised' crime: all five firearms dealers identified within the case are linked through their presence in one network and it is not farfetched to assume they know each other.

Structurally speaking, the case study does not reveal a coherent terrorist network in the Netherlands. Rather, we find many smaller sub-networks that contain a few terrorist suspects and many criminals who interact with each other. One conclusion is therefore that at the individual level, there is an interwovenness or interconnectedness between criminals and terrorists (who often are or have been criminals themselves). In some cases, terrorist suspects per- 
form a central role in a network, or act as a 'bridge' between otherwise unconnected networks. However, this cannot be qualified as an organised crime nexus: that would require a more comprehensive, structural interface between the two types of networks.

At the same time, as we have not seen a coherent terrorist organisation emerge from our data, it logically follows that based on our study it cannot be concluded that there is an interwovenness of organised crime and terrorism at the group or structural level.

In relation to this point, it is important to explicitly note that the absence of interwovenness also (logically) cannot be confirmed: we have not seen these networks in our case, but this absence could be caused either by their non-existence or be a result of the scope of the study. Perhaps these would have emerged if the network were mapped to one additional degree of relations. The arrests of a number of terrorist suspects last year ( 2 in June, 7 in September and 5 in December 2018; see Trouw, 29 December 2018), who have all been charged with membership of a terrorist network and with conspiring to plan a terrorist attack, indicates that looser terrorist networks or cells are present in the Netherlands. It is important to monitor the progress of these court cases, to identify the nature of these looser networks and, in case these suspects had already acquired weapons, to trace how these have been obtained.

\section{Discussion and the way forward}

\section{a. Avenues for further research}

Our study has been able to draw on primary sources from the police in order to build our SNA database. Coding has been based on police files, validated and complemented by inputs from specialised police teams. It has not been possible to include 'richer' information on the context of specific cases and subjects, which would be present with the detectives responsible for working the cases. As a result, our research has been able to lay bare the 'bone structure' of the networks. 
A fruitful next step would be to 'put some flesh on the bones' by involving those detectives and enriching the analysis with a contextual understanding. Subject $a$ is related to subject $b$, but are they casual acquaintances, close friends, or partners turned enemies? Did they actually know each other? ${ }^{4}$ Firearms dealer $x$ knows terrorist subject $y$, but what is the meaning of this relationship - are they childhood friends, or 'accidentally' connected by a common acquaintance? Considering how labour-intense this unravelling could be, our suggestion would be to focus on the 15 persons that our SNA has highlighted as being of particular relevance, due to (the combination of) their personal characteristics and their position in their respective networks.

Based on the experience gained during the study, SNA is a very fruitful approach for further (applied) criminological research. The method is scalable, so that any characteristic or type of relationship that is deemed relevant can be included in a specific model.

The method is also adaptive: it can relatively easily be applied to other areas of interest, such as outlaw motor gangs and the drugs trade. The only limiting precondition is that sufficient data needs to be available. Through combining primary data from police databases with expert knowledge from specialist police teams (further complemented by outside experts), this is a hurdle that can be overcome.

Although coding of the subjects and the creation of the database can be time-consuming, on the whole the method could prove to be a time saver for police analysts and investigators, for whom the need to prioritise is immense. Using network positions and personal characteristics, it is possible to identify a select number of key subjects, on whom an investigation could usefully focus.

In addition, mapping the structure of a network allows previously unseen (because indirect) links between phenomena to be recognised, and potential blind spots to be discovered more easily. Police work would stand to gain from more structurally implementing these approaches.

4 In the worst case, they could have been incidentally lumped together in the system by careless registration. 
In our case, some 15 subjects already known to the police have been flagged as of interest for further investigation, and two new subjects have been flagged as of interest from a counter-terrorism and radicalism perspective.

\section{b. Reflections on the applicability for police work}

Although SNA is not an alien methodology for many police analysts, it seems that mapping of a social network often only occurs on a subject basis (who is this suspect in contact with?) and not on a phenomenon or more strategic level (what, if any, are the links between different criminal groups?).

The applied method of systematically combining information from different fields of expertise (in our case: intelligence on firearms and on terrorism) leads to new insights. The added value can be seen on two levels:

- By mapping the social network of suspects, relationships are uncovered that may be instructive when assessing threats and whom to prioritise. A systematic approach allows for clear-cut choices in this prioritisation, which can lead to more efficient use of resources (personnel, time and money).

- Regular cross-checks of actors from different fields (firearms dealers, extremists, firearms users), their connections, density of their networks can lead to the identification of overlap between phenomena that had not been recognised before. This furthers our (theoretical) understanding of the subjects of this study

A further deepening of this theme is recommended as a result of this exploration. In the context of this research, a number of concrete possibilities have been described for how to apply SNA within the police agencies to this theme and related issues. SNA can support the process of gathering further information regarding the nexus of organised crime and terrorist jihadi groups, and can assist in the decision-making concerning how to prioritise follow-up investigatory work. 


\section{c. Limitations and opportunities for further research}

A fundamental question is to what extent social structures can meaningfully be captured with the network model. This discussion is beyond the scope of this article, although we note that the often transactional nature of criminal relations would seem a priori to be suitable for a network model.

In addition, this study has some more specific limitations that need to be recognised - which hint at opportunities for further fruitful research. These fall into three categories:

- Data: the information (made) available to us was limited to primary data from the police databases, supplemented by specialist expertise. Further research would benefit from involving detectives involved in specific cases. Concretely, one should consult the investigators who have 'human intelligence' on those identified as key actors within a social network.

- Reliability: it is known that primary police databases suffer from a certain level of data pollution as a result of incorrect or incomplete registrations. Researchers should recognise this, and adopt the strategy outlined in the previous point: consult the relevant detectives.

- Robustness: our findings are liable to change if further layers of connections are added to the network. It could be that such an expansion of the network in will reveals for example, a network of loosely federated terrorist cells. Future studies need to keep in mind that there should be a balance between on the one hand 'completeness' of the networks, and on the other the strength of the connections thus discovered (to what extent are third-degree connections indicative of a robust organisation?), compounded by practical concerns about the trade-off with the time spent on gathering and interpreting the data. 


\section{References}

Adviesraad Internationale Vraagstukken, Criminaliteit, Corruptie en Instabiliteit: een Verkennend Advies'. Advies. The Hague: AIV, 2013.

Basra R., P. Neumann and C. Brunner C., Criminal pasts, terrorist futures: European jihadists and the new crime-terror nexus. London: ICSR, 2016.

Bie, J.L. de, How jihadist networks operate. A grounded understanding of changing organizational structures, activities, and involvement mechanisms of jihadist networks in the Netherlands. Leiden: Universiteit Leiden, 2016.

Boerman, F. and M. Bruinsma, De illegale handel in vuurwapens en explosieven. Zoetermeer: Dienst Nationale Recherche Informatie, 2012.

Borgatti, S.P., Centrality and network flow. Social Networks, 2005, 27(1), 5571.

Bruinsma, M. and H. Moors, Illegale vuurwapens. Gebruik, bezit en handel in Nederland, 2001 - 2003. Tilburg: IVA, 2005.

Burt, R.S., Structural holes: The social structure of competition. Cambridge, Mass.: Harvard University Press, 1992.

Centre for Strategy and Evaluation Services, Study to Support an Impact Assessment on Options for Combatting Illicit Firearms Trafficking in the European Union. European Commission: DG Migration and Home Affairs, 2014.

Der Spiegel / European Investigative Collaboration (24 March 2016), 'How EU Failures Helped Terrorists Obtain Weapons'.

Dienst Nationale Recherche, 'Illegale wapenhandel'. In Justitiële Verkenningen, 2006, 4(8).

Duquet N., Armed to kill: An exploratory analysis of the guns used in recent public mass shooting in Europe. Brussels: Flemish Peace Institute, 2016.

Duquet N. (2016), 'Firearms acquisition and the terrorism-criminality nexus'. In Renard T. (ed.), Counterterrorism in Belgium: key challenges and policy options. Egmont Institute: Egmont Paper 89, 2016.

Dutch National Police, Nationaal Dreigingsbeeld 2017, 2017.

Europol, European Union Terrorism Situation and Trend Report 2015. The Hague: Europol, 2015. 
Flemish Peace Institute, Project SAFTE. Brussels: European Commission Directorate-General for Migration and Home Affairs, 2018.

Freeman L.C. and S.P. Borgatti, Centrality in valued graphs. Social Networks, 1991, 13(2), 141-154.

Gerring J., Case study research. principles and practices. Cambridge: Cambridge University Press, 2007.

Hanneman, R.A. and M. Riddle, Introduction to social network methods. Riverside, CA: University of California, Riverside, 2005.

Hübschle A., 'From Theory to Practice: Exploring the organized crime-terror nexus in Sub-Saharan Africa'. Perspectives on Terrorism, 2011, 5(3-4).

Laqueur, W., The new terrorism. Oxford: Oxford University Press, 2000.

Makarenko, T., The terror-crime continuum: tracing the interplay between transnational organised crime and terrorism, 2004

Makarenko, T, and M. Mesquitaa, 'Categorising the crime-terror nexus in the European Union', Global Crime, 2014, 15(3-4), 259-274.

NCTV, Beleidsimplicaties dreigingsbeeld terrorisme Nederland 38. The Hague: NCTV, 7 April 2015.

NRC, 'Hoe het vuurwapengeweld in Nederland explodeerde', 13 July $2016 \mathrm{a}$.

NRC, 'Onderzoek naar Slowaakse wapens in Nederland', 13 July $2016 \mathrm{~b}$.

NRC, 'De Slowakijeroute en het terrorisme', 15 July 2016.

Poot, C.J. de and A. Sonnenschein, 'Jihadistisch terrorisme in Nederland. Een beschrijving op basis van afgesloten opsporingsonderzoeken'. In Onderzoek en beleid no281. The Hague: WODC, 2009.

Trouw, 'Politie Rotterdam arresteert verdachten in terrorisme-onderzoek', 29 December 2018

Veldhuis T., Prisoner radicalization and terrorism detention policy: Institutionalized fear or evidence-based policy making? London: Routledge, 2016.

Wasserman, S. and K. Faust, Social Network Analysis. Methods and Applications. New York: Cambridge University Press, 1994.

West Sands Advisory LLP, Europe's crime-terror nexus: links between terrorist and organized crime groups in the European Union. Brussels: European Parliament, Directorate-General for Internal Policies, Policy Department Citizens' Rights and Constitutional Affairs, 2012. 